\title{
Patent Office decision puts Genentech out in front
}

\section{- Broad claims of biotech company granted - Courts will decide ultimate value}

\section{Washington}

A BROAD patent covering molecular biological tools used to create proteins from genetically engineered organisms was granted to Genentech last week by the US Patent and Trademark Office. The patent encompasses techniques used by the entire biotechnology industry, and may entitle Genentech to collect royalties from every company selling products made by genetic engineering.

Genentech's patent is being compared to the Cohen-Boyer patent that launched the biotechnology industry. The CohenBoyer patent covered techniques of gene splicing and expression of certain genes that marked transformants. Genentech's patent is subservient to the Cohen-Boyer patent, so anyone seeking to license from Genentech will first require a licence from the University of California and Stanford University, the patent's co-holders. Since the Cohen-Boyer patent was awarded in 1980, the universities have received approximately $\$ 6$ million in royalties.

The patent includes 15 claims; some exceedingly specific, and others sweepingly broad. The first and broadest claim establishes Genentech's proprietary right over any "recombinant DNA cloning vehicle suitable for the transformation of a microbial host" that consists of a control region regulating the expression of a structural gene, where the gene coding for the polypeptide is in the correct reading frame for expression, and the polypeptide is in recoverable form. The other 14 claims cover specific plasmids used as cloning vehicles, including those containing the Escherichia coli lac and tryptophan operon-promoter systems. Genentech also lays claim to plasmids that produce mammalian hormones or polypeptides in general, and specifically ones that produce proinsulin, growth hormone, and the $\mathrm{A}$ and $\mathrm{B}$ chains of human insulin.

Genentech filed for the patent in 1977 when the enormous commercial potential of biotechnology was just being recognized. The patent office delayed its decision on Genentech's patent until the 1980 Supreme Court decision in Diamond vs Chakrabarty cleared the way for the patenting of living things produced by human intervention. The next seven years, according to the company, were spent establishing the priority of some of the claims over work done at the University of California.

In announcing the patent, Genentech's
Thomas Kiley said the company would pursue an open nonexclusive licensing policy. He indicated that it was too early to tell what the royalty rate would be, and that the company would wait until the companies using the technology had sufficient time to approach Genentech for a licence before prosecuting infringers. Genentech will only be eligible for royalties from products after 3 November 1987 , the issue date of the patent.

But some say that the patent is not that all-encompassing because it makes no mention of the increasingly popular mammalian cell expression systems, and may not even cover some special microbial systems. Patent attorneys point out that the proof of a patent's value does not come until it is challenged in court. Just because the patent does not expressly cover mammalian expression systems, the courts may nonetheless rule that it is applicable to such systems.

Attorney Jorge Goldstein, of Saidman, Sterne, Kessler and Goldstein, says Genentech could insulate its broader claims from scrutiny by using one of the more specific claims of the patent. In this scheme, a firm sued for infringing one of the more specific claims could not argue against more than the one claim in its suit.

Most of the smaller biotechnology companies are expected to come forward and seek licences from Genentech. It is in the biotech industry's best interest to be pro-patent while the industry is just getting started,"and small companies will not want to risk being put out of business trying to oppose a patent that they can license easily. Potential opposition could come from larger pharmaceutical firms with in-house biotech programmes, such as Eli Lilly. According to a Lilly spokesperson, Lilly "will be unaffected by the [Genentech] patent", even though Lilly markets a competitor to Genentech's human growth hormone that is also produced using recombinant DNA techniques. Lilly would have the resources to contest the patent, but legally would have to wait until it received an infringement suit, or at least a letter threatening a suit, before it could mobilize. Most of Genentech's products, both on the market and under development, are also being worked on by other companies. Genentech could use the patent to lock out competitors, and potentially even competitors with protein-engineered or "second generation" products. Carol Ezzell

\section{New radiotelescopes}

THE University of California at Berkeley is to add 3 six-metre radiotelescopes to its Hat Creek Radio Observatory near Mt Lassen in northern California.

The \$3.6-million project, a joint venture of the Universities of California, of Maryland and of Illinois, will increase the data collection capabilities of the observatory fivefold. Data from Hat Creek will be fed to powerful new computer facilities at Illinois and Maryland.

M.B.

\section{Einstein for sale}

A hitherto unknown manuscript on relativity, written by Einstein in 1912, will be auctioned at Sotheby's in New York on 2 December. At 72 pages it is one of the

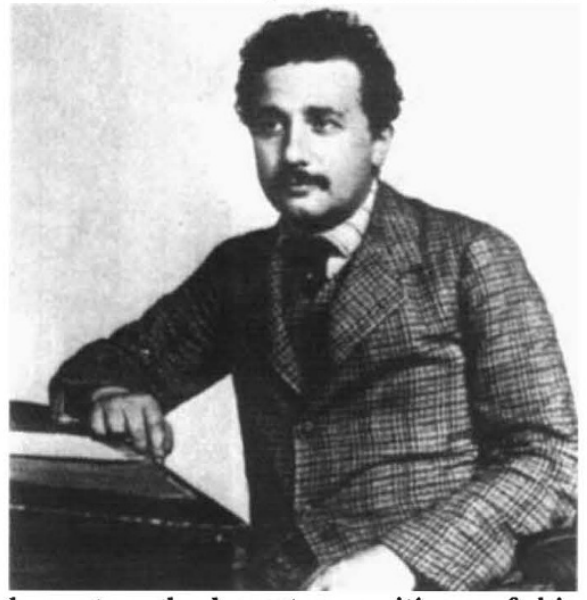

longest and clearest expositions of his theory and casts new light on the development of his thinking. Bids of up to $\$ 700,000$ are expected for the manuscript.

Written in German, it was intended as a chapter for the Handbuch der Radiologie that Professor Erich Marx of Leipzig published in five volumes between 1913 and 1925. Unpublished correspondence between Marx and Einstein suggests that its publication was halted by the First World War.

S.J.H.

\section{Biotech expansion}

THE European Commission is calling for a £14-million expansion of its biotechnology programme to update information systems, improve training and make room for new European Community members Spain and Portugal. The present $£ 38$ million programme expires in 1989. A five-year follow-on programme is scheduled to start in 1990.

B.C.

\section{UNESCO's new head}

THE appointment of Spanish molecular biologist Frederico Mayor as the director general of UNESCO was formally ratified on 7 November. At a full assembly of UNESCO member states in Paris, Mayor received 142 votes out of 149 , to replace the controversial Amadou Mahtar M'Bow of Senegal (see Nature 329, 659; 1987). 